\title{
ПОРІВНЯЛЬНИЙ АНАЛІЗ ФАКТОРІВ РИЗИКУ ТА КЛІНІЧНИХ ПОКАЗНИКІВ ТЯЖКОСТІ СТАНУ ПАЦІЕНТІВ ІЗ ТРАНЗИТОРНИМИ ІШЕМІЧНИМИ АТАКАМИ ТА В РІЗНІ ПЕРІОДИ ІШЕМІЧНОГО ІНСУЛЬТУ
}

НДІ реабілітації інвалідів Вінницького національного медичного університету ім. М. І. Пирогова

\begin{abstract}
Резюме. У статті наведено порівняльний аналіз факторів ризику та клінічних показників тяжкості стану пацієнтів із транзиторними ішемічними атаками та в різні періоди ішемічного інсульту. Встановлено, що серед факторів ризику цереброваскулярної патології перше місце посідає артеріальна гіпертензія (у 80 \%), друге місце - тютюнопаління (у 40 \%), ожиріння виявлено у третини пацієнтів, ішемічна хвороба серця - у
\end{abstract}

Вступ. Цереброваскулярні захворювання належать до найбільш розповсюджених неінфекційних хвороб і найчастіших захворювань нервової системи, а їх найнебезпечніша форма - гостре порушення мозкового кровообігу - трапляється частіше, ніж гострий інфаркт міокарда. Інсульт $€$ завершальною стадією цереброваскулярних розладів і виникає, як правило, на тлі тривалого існування початкових проявів порушень кровопостачання мозку, епізодів транзиторних ішемічних атак (ТІА). Поширеність цих розладів $\epsilon$ досить високою, особливо серед осіб літнього та старечого віку $[2,4,5]$. За даними ВОО3, щорічно у світі реєструється більше 15 млн випадків інсульту. Більш ніж половина 3 цих пацієнтів помирають протягом першого року $[3,4,6]$. Повторні ішемічні атаки та інсульти після перенесеного первинного інсульту реєструються в 11-32 \% [2, 7, 10, 13]. Так, протягом перших 30 діб частота розвитку повторного ішемічного інсульту становить 7$8 \%$, першого року - 6-20\%, п’яти років - 25$32 \%$. Серед тих осіб, що вижили, до $80 \%$ залишаються інвалідами і лише 20 \% можуть повернутися до праці.

В останні роки в Україні та за кордоном велику увагу приділяють вивченню факторів ризику розвитку судинних катастроф та їх ролі в прогресуванні цереброваскулярної патології (ЦВП) $[3,4,8,9]$. Широко обговорюється роль традиційних факторів ризику таких, як вік, ожиріння, неконтрольована артеріальна гіпертензія, атеросклероз, цукровий діабет, паління та ін. $[4,6,11$, 12]. Поряд 3 цим, епідеміологічна ситуація щодо поширеності традиційних факторів ризику в Україні та їх зв'язок із тяжкістю перебігу ЦВП залишаються до кінця не з'ясованими.

Мета дослідження. Вивчення факторів ризику ЦВП та клінічних показників тяжкості стану в пацієнтів із транзиторними ішемічними атаками та в різні періоди ішемічного інсульту.

Матеріал і методи. Під нашим спостереженням перебували 183 пацієнти із ЦВП. Чоловіків було 85 (46\%), жінок - 98 (54 \%). Вік пацієнтів у

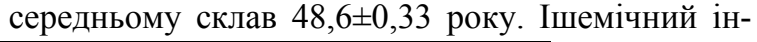

10 \%. Тяжкість стану пацієнтів, вираженість порушення життєвих та когнітивних функцій залежать від типу інсульту та епізодів повторного порушення мозкового кровообігу.

Ключові слова: фактори ризику, артеріальна гіпертензія, ішемічна хвороба серця, ожиріння, паління, інсульт.

сульт діагностовано в 153 осіб, ТІА - у 30. Розподіл пацієнтів за статтю не виявив достовірних розбіжностей у цих групах, а середній вік осіб з TIA був дещо меншим (на 6,7 \%), ніж у пацієнтів 3 інсультами.

Всім пацієнтам проведено загальноклінічне, неврологічне, інструментальне, офтальмологічне та лабораторне обстеження. 3 метою верифікації діагнозу проводили дуплексне ультразвукове сканування інтра- та екстракраніальних судин, СКТ та МРТ головного мозку.

Для визначення тяжкості ішемічного інсульту застосовували стандартизовані шкали [1]. У гострому періоді використовували шкалу NIH (National Institutes of Health Stroke Scale) [1], яка дозволяла визначити ступінь тяжкості свідомості і неврологічного дефіциту при надходженні пацієнта і в динаміці. Для оцінки ступеня інвалідизації та функціональної незалежності хворого в ранньому відновному, пізньому відновному та резидуальному періодах використовували шкалу Ренкіна. Когнітивні функції оцінювали за допомогою Міні-Ментал Тесту. Визначення м'язової сили проводили за шестибальною шкалою оцінки м'язової сили. Ступінь еластичності оцінювали за модифікованою шестибальною шкалою спастичності Ашфорта.

Статистичний аналіз матеріалу проводився за допомогою стандартних методів із застосуванням пакета прикладних програм «MS Excel XP» та «Statistica SPSS 10.0 for Windows» (ліцензійний № 305147890). Для оцінки міжгрупової різниці застосовували параметричний t-критерій Стьюдента, при визначені зв'язків між показниками - кореляційний аналіз за Пірсоном та ранговий - за Спірманом, при порівнянні частоти змін - критерій Фішера.

Результати дослідження та їх обговорення. Проведено аналіз розподілу пацієнтів за найбільш вагомими факторами ризику ЦВП, таких, як артеріальна гіпертензія, ішемічна хвороба серця, ожиріння та тютюнопаління. Встановлено, що як серед осіб з ТІА, так і серед осіб $з$ інсультами перше місце за частотою посідає артеріальна гіпертензія 
Таблиця 1

Стать та деякі фактори ризику паціснтів із цереброваскулярними захворюваннями

\begin{tabular}{|c|c|c|c|c|c|c|}
\hline Групи пацієнтів & Жінки & Чоловіки & $\begin{array}{l}\text { Артеріальна } \\
\text { гіпертонія }\end{array}$ & $\begin{array}{l}\text { Ішемічна } \\
\text { хвороба }\end{array}$ & Ожиріння & $\begin{array}{l}\text { Паління } \\
\text { тютюну }\end{array}$ \\
\hline $\begin{array}{l}\text { Всі пацієнти з це- } \\
\text { ребровас- } \\
\text { кулярною патоло- } \\
\text { гією, } \mathrm{n}=183\end{array}$ & $\begin{array}{c}98 \\
54 \%\end{array}$ & $\begin{array}{c}85 \\
46 \%\end{array}$ & $\begin{array}{c}86 \\
47 \%\end{array}$ & $\begin{array}{c}15 \\
8 \%\end{array}$ & $\begin{array}{c}55 \\
30 \%\end{array}$ & $\begin{array}{c}68 \\
37 \%\end{array}$ \\
\hline $\begin{array}{l}\text { Транзиторні ішемі- } \\
\text { чні атаки, } n=30\end{array}$ & $\begin{array}{c}16 \\
53 \%\end{array}$ & $\begin{array}{c}14 \\
47 \%\end{array}$ & $\begin{array}{c}14 \\
47 \%\end{array}$ & $\begin{array}{c}1 \\
3 \%\end{array}$ & $\begin{array}{c}4 \\
13 \%\end{array}$ & $\begin{array}{c}6 \\
20 \%\end{array}$ \\
\hline $\begin{array}{c}\text { Пацієнти з інсуль- } \\
\text { том, } \\
\text { n=153 } \\
\end{array}$ & $\begin{array}{c}82 \\
54 \%\end{array}$ & $\begin{array}{c}71 \\
46 \%\end{array}$ & $\begin{array}{c}72 \\
80 \%\end{array}$ & $\begin{array}{c}14 \\
9 \%\end{array}$ & $\begin{array}{c}51 \\
33 \%\end{array}$ & $\begin{array}{c}62 \\
41 \%\end{array}$ \\
\hline $\mathrm{p}$ & 0,5 & 0,5 & 0,5 & 0,1 & 0,02 & 0,02 \\
\hline \multicolumn{7}{|c|}{ У тому числі } \\
\hline $\begin{array}{c}\text { Гострий період } \\
\text { інсульту, } \\
\text { n=29 }\end{array}$ & $\begin{array}{c}12 \\
41 \%\end{array}$ & $\begin{array}{c}17 \\
59 \%\end{array}$ & $\begin{array}{c}16 \\
55 \%\end{array}$ & $\begin{array}{c}2 \\
7 \%\end{array}$ & $\begin{array}{c}8 \\
28 \%\end{array}$ & $\begin{array}{c}16 \\
55 \%\end{array}$ \\
\hline $\begin{array}{c}\text { Ранній відновний } \\
\text { період інсульту, } \\
\text { n=39 } \\
\end{array}$ & $\begin{array}{c}19 \\
49 \%\end{array}$ & $\begin{array}{c}20 \\
51 \%\end{array}$ & $\begin{array}{c}18 \\
46 \%\end{array}$ & $\begin{array}{c}3 \\
8 \%\end{array}$ & $\begin{array}{c}11 \\
28 \%\end{array}$ & $\begin{array}{c}15 \\
38 \%\end{array}$ \\
\hline $\begin{array}{c}\mathrm{p} \text { щодо гострого } \\
\text { періоду }\end{array}$ & 0,5 & 0,5 & 0,5 & 0,5 & 0,5 & 0,1 \\
\hline $\begin{array}{c}\text { Пізній відновний } \\
\text { період, } \\
\text { n=35 } \\
\end{array}$ & $\begin{array}{c}18 \\
51 \%\end{array}$ & $\begin{array}{c}17 \\
49 \%\end{array}$ & $\begin{array}{c}11 \\
31 \%\end{array}$ & $\begin{array}{c}2 \\
6 \%\end{array}$ & $\begin{array}{c}11 \\
31 \%\end{array}$ & $\begin{array}{c}11 \\
31 \%\end{array}$ \\
\hline $\begin{array}{c}\mathrm{p} \text { щодо гострого } \\
\text { періоду }\end{array}$ & 0,5 & 0,5 & 0,1 & 0,5 & 0,5 & 0,05 \\
\hline $\begin{array}{c}\text { Віддалені наслідки } \\
\text { інсульту, } \\
\text { n=50 } \\
\end{array}$ & $\begin{array}{c}33 \\
66 \%\end{array}$ & $\begin{array}{c}17 \\
34 \%\end{array}$ & $\begin{array}{c}27 \\
54 \%\end{array}$ & $\begin{array}{c}7 \\
14 \%\end{array}$ & $\begin{array}{c}21 \\
42 \%\end{array}$ & $\begin{array}{c}20 \\
40 \%\end{array}$ \\
\hline $\begin{array}{c}\mathrm{p} \text { щодо гострого } \\
\text { періоду }\end{array}$ & 0,5 & 0,5 & 0,5 & 0,5 & 0,2 & 0,2 \\
\hline
\end{tabular}

Таблиця 2

Характеристика тяжкості стану пацієнтів з інсультами

\begin{tabular}{|c|c|c|c|c|}
\hline & $\begin{array}{c}\text { Порушення життє- } \\
\text { вих функцій за } \\
\text { шкалою Ренкіна }\end{array}$ & $\begin{array}{l}\text { Порушення когні- } \\
\text { тивних функцій }\end{array}$ & $\begin{array}{c}\text { М'язова сила, } \\
\text { бали }\end{array}$ & $\begin{array}{l}\text { Виразність спас- } \\
\text { тичності, бали }\end{array}$ \\
\hline $\begin{array}{l}\text { Пацієнти з інсультом, } \\
\text { n=153 }\end{array}$ & $2,44 \pm 0,10$ & $23,1 \pm 0,19$ & $2,84+0,12$ & $1,54+0,14$ \\
\hline \multicolumn{5}{|c|}{ У тому числі } \\
\hline $\begin{array}{c}\text { Гострий період інсульту, } \\
\text { n=29 }\end{array}$ & $10,7+0,78^{*}$ & - & $2,28+0,30$ & $1,03+0,25$ \\
\hline $\begin{array}{l}\text { Ранній відновний період інсульту, } \\
\text { n=39 }\end{array}$ & $2,41+0,17$ & $23,2+0,37$ & $3,21+0,20$ & $1,51+0,26$ \\
\hline $\begin{array}{l}\text { Пізній відновний період, } \\
\text { n=35 }\end{array}$ & $2,66 \pm 0,17$ & $22,7+0,34$ & $2,69+0,22$ & $2,11+0,30$ \\
\hline Віддалені наслідки інсульту, n=50 & $2,30 \pm 0,16$ & $23,2+0,30$ & $2,98+0,21$ & $1,44+0,26$ \\
\hline
\end{tabular}

(у 80 \% осіб в обох групах) (табл. 1). На другому місці було паління тютюну, причому відсоток курців серед пацієнтів з інсультами достовірно переважав (у 2,0 раза) кількість таких серед осіб 3 TIA. Крім того, у пацієнтів з інсультами вдвічі частіше виявлялось ожиріння. Ішемічна хвороба серця діагностована у $9 \%$ осіб з інсультами та в $3 \%$ осіб з TIA.
Нами не виявлено статистичних відмінностей у частоті досліджуваних факторів ризику залежно від періоду інсульту, лише серед хворих у ранньому та пізньому відновних періодах спостерігалася тенденція до зменшення частки курців тютюну.

Як свідчать дані, наведені в табл. 2, порушення життєвих функцій у пацієнтів 3 інсультом (за винятком гострого періоду) за шкалою Ренкіна в 
Таблиця 3

Характеристика тяжкості стану паціснтів 3 інсультами 3 відсутністю або наявністю в анамнезі транзиторних ішемічних атак та інсультів

\begin{tabular}{|c|c|c|c|c|c|}
\hline $\begin{array}{c}\text { Пацієнти, що перенесли } \\
\text { інсульт }\end{array}$ & Вік & Жінки & Чоловіки & $\begin{array}{c}\text { Порушення } \\
\text { життєвих функ- } \\
\text { цій за шкалою } \\
\text { Ренкіна }\end{array}$ & $\begin{array}{c}\text { Порушення } \\
\text { когнітивних } \\
\text { функцій }\end{array}$ \\
\hline $\begin{array}{c}\text { Пацієнти з первинним інсу- } \\
\text { льтом, п=88 }\end{array}$ & $48,7 \pm 0,45$ & $\begin{array}{c}47 \\
53 \%\end{array}$ & $\begin{array}{c}41 \\
47 \%\end{array}$ & $2,25 \pm 0,13$ & $23,5+0,24$ \\
\hline $\begin{array}{c}\text { Пацієнти з ТІА в анамнезі, } \\
\text { п=41 }\end{array}$ & $49,4 \pm 0,62$ & $\begin{array}{c}23 \\
56 \%\end{array}$ & $\begin{array}{c}18 \\
44 \%\end{array}$ & $2,47+0,19$ & $22,9 \pm 0,36$ \\
\hline $\begin{array}{c}\text { Пацієнти з повторним інсу- } \\
\text { льтом, } \\
\text { п=24 }\end{array}$ & $50,2 \pm 0,58$ & $\begin{array}{c}12 \\
50 \%\end{array}$ & $3,05 \pm 0,20$ & $21,5 \pm 0,43$ \\
\hline $\begin{array}{c}\text { р щодо пацієнтів з первинним } \\
\text { інсультом }\end{array}$ & 0,1 & 0,5 & 0,5 & 0,01 & 0,01 \\
\hline
\end{tabular}

середньому становило 2,44 $\pm 0,10$ бала, що відповідає неврологічним порушенням середнього ступеня тяжкості. Порушення життєвих функцій у пацієнтів у гострому періоді інсульту за шкалою $\mathrm{NIH}$ також відповідало порушенням середньої тяжкості і становило $10,7 \pm 0,78$ бала.

В усіх групах, незалежно від періоду інсульту (за винятком гострого періоду), виявлялись істотні порушення когнітивних функцій - середній бал за шкалою Mini-Mental у жодній групі не перевищував 24 (гранична межа). При оцінці рухових функцій встановлено, що в пацієнтів у гострому періоді інсульту м'язова сила була достовірно меншою (на 40,7 \%) порівняно 3 раннім відновним періодом $(\mathrm{p}<0,05)$. У пацієнтів у резидуальному періоді цей показник був дещо меншим, ніж у ранньому відновному, але достовірно перевищував такий у хворих у гострому періоді на $30,7 \%$ ( $<0,05)$. Виразність еластичності була максимальною у пацієнтів у пізньому відновному періоді (у 2,0 раза вище порівняно з гострим періодом $\mathrm{p}<0,05)$, у той час як в інші періоди інсульту достовірних відмінностей між групами за цим показником не спостерігалось.

Клінічна характеристика хворих 3 різними типами ішемічного інсульту показала, що групи пацієнтів із каротидним та стовбуровим інсультом були репрезентативними за статтю та факторами ризику, лише середній вік пацієнтів зі стовбуровим інсультом був дещо нижчим, ніж в осіб із каротидним інсультом (на 5,5 \%). Серед факторів ризику в обох групах перше місце посідала артеріальна гіпертензія (виявлена у 80 \% пацієнтів у середньому), на другому місці було паління тютюну (біля $40 \%$ осіб), ожиріння виявлено у третини пацієнтів, ішемічна хвороба серця - у $10 \%$. Подальший аналіз показав, що в пацієнтів із кардіоемболічними інсультом у 12 разів частіше трапляється ішемічна хвороба серця, ніж у осіб з атеротромботичним інсультом, а серед осіб із лакунарним та гемодинамічним інсультом відсоток курців тютюну перевищує 50 \%.

Групи пацієнтів із каротидним та стовбуровим інсультом за тяжкістю стану були репрезентативними. Зокрема, за середніми величинами порушення життєвих функцій за шкалою Ренкіна, ступенем порушення когнітивних функцій, м'язовою силою, виразністю еластичності достовірних відмінностей між згаданими групами не виявлено.Тяжкість стану пацієнтів залежно від підтипу інсульту за вищезазначеними показниками також була практично однаковою. У пацієнтів із лакунарним інсультом порушення життєвих функцій, зниження м'язової сили, виразність еластичності були достовірно меншими (в 1,7, 1,5 та 2,1 раза, відповідно), а порушення когнітивних функцій більшими (на 6,1 \%), ніж у осіб з атеротромботичним інсультом. У пацієнтів із гемодинамічним інсультом порушення життєвих функцій за шкалою Ренкіна були достовірно меншими (на 88,0 \%), а м'язова сила та порушення когнітивних функцій більшими (на 76,7 \% та 8,7 \%, відповідно).

На наступному етапі роботи проведено порівняльне дослідження тяжкості стану пацієнтів 3 інсультами залежно від наявності чи відсутності в анамнезі ТІА. Як свідчать дані, наведені в табл. 3, всі групи пацієнтів були репрезентативними за статтю та віком. За ступенем порушення життевих функцій, визначеним за шкалою Ренкіна, пацієнти 3 первинними інсультами достовірно не відрізнялись від осіб, які в анамнезі вже мали ТІА. Когнітивні функції у пацієнтів зазначених груп також погіршувалися практично в рівній мірі. У той же час, в осіб із повторним інсультом тяжкість стану за шкалою Ренкіна та порушення когнітивних функцій були значно більшими (на 35,5 та 9,3\%, відповідно), ніж у осіб із первинними інсультами.

\section{Висновки}

1. Серед факторів ризику цереброваскулярної патології перше місце посідає артеріальна гіпертензія, яка реєструється у 80 \% пацієнтів з інсультом (за винятком гемодинамічного) і в $47 \%$ пацієнтів 3 транзиторними ішемічними атаками. На другому місці знаходиться паління тютюну, причому серед осіб з інсультом курців вдвічі більше, ніж серед осіб з транзиторними ішемічними атаками (41\%) та $20 \%$ ), відповідно), а серед пацієнтів із 
лакунарним та гемодинамічним інсультом кількість курців становила 50 \%. Ожиріння також траплялося у 2,5 раза частіше в осіб з інсультом, ніж у осіб з транзиторними ішемічними атаками. Ішемічна хвороба серця виявлялась лише у 3-9 \% пацієнтів 3 цереброваскулярною патологією за винятком осіб iз кардіоемболічним інсультом, у яких частота цієї патології зростала до 24 \%.

2. У пацієнтів із атеротромботичним та кардіоеміболічним типом інсульту життєві функції, м'язова сила та еластичність порушувалися більш істотно, ніж у пацієнтів 3 лакунарним та гемодинамічним інсультом (у пацієнтів з атеротромботичним інсультом показник за шкалою Ренкіна на 7080 \% вищий, ніж у осіб із лакунарним інсультом). У пацієнтів із лакунарним і гемодинамічним інсультом більшою мірою (на 6-8 \%) страждали когнітивні функції порівняно 3 атеротромботичним інсультом. У пацієнтів із повторними інсультами спостерігалися більш тяжкі порушення життєвих (на 30-35 \%) та когнітивних функцій (на 8-10 \%), ніж у осіб із первинними інсультами.

3. Наявність транзиторних ішемічних атак в анамнезі меншою мірою впливала на показники тяжкості стану осіб з ішемічним інсультом.

Перспективи подальших досліджень направлені на розробку та впровадження патогенетично обгрунтованих методів первинної профілактики, лікування та реабілітації хворих із порушеннями мозкового кровообігу.

\section{Лiтература}

1. Белова А.Н. Шкалы, тесты и опросники в неврологии и нейрохирургии. - М.: Видавництво «Самарский дом печати», 2004. $-434 \mathrm{c}$.

2. Гусев Е.И. Информированность населения о факторах риска сосудистых заболеваний головного мозга и клинических проявлениях инсульта / Е.И. Гусев, Я.Е. Фрис, Л.А. Шелякина // Ж. неврол. и психиатрии им. С.С. Корсакова. - 2010. - Т. 110, № 9. - С. 3-12.

3. Евтушенко С.К. От этиологии и подвидов инсультов у лиц молодого возраста - к их эффективному лечению и профилактике / С.К. Евтушенко: матеріали XII Міжнародної конференції [«Актуальні напрямки в неврології: сьогодення та майбутнє»]. - Судак, 2010. C. $12-18$

4. Мищенко Т.С. Факторы риска и клинические особенности у больных с различными подтипами ишемического инсульта / Т.С. Мищенко, Н.В. Овсянникова, В.В. Лебединец // Междунар. мед. ж. - 2011. - № 3. C. 27-32.

5. Олейник И.В. Состояние и перспективы решения мозковых инсультов, их социально-медицинских последствий (обзор литературы) / И.В. Олейник // Вісн. морфол. - 2010. - Вип. 16 (3). - С. 734-737.

6. Торгало Є.О. Інсульт: фактори ризику та методи лікування / С.О. Торгало, Л.І. Остапченко // Фізика живого. - 2010. - Т. 18, № 3. - С. 39-41.

7. Allen C.L. Risk factors for ischaemic stroke / C.L. Allen, U. Bayraktutan // Int. J. Stroke. - 2008. Vol. 3, № 2. - P. 105-16.

8. Brethour M.K .Controversies in acute stroke treatment / M.K. Brethour, K.V. Nyström, S. Broughton // AACN Adv Crit Care. - 2012. - Vol. 23, № 2. - P. 158-72.

9. Culmsee C. Ischaemic brain damage after stroke: new insights into efficient therapeutic strategies International Symposium on Neurodegeneration and Neuroprotection / C. Culmsee, J. Krieglstein // EMBO reports. - 2007. Vol. 8, № 2. - P. 129-133.

10. Johnston D.C. The patient with transient cerebral ischemia: a golden opportunity for stroke prevention / D.C. Johnston, M.D. Hill // CMAJ. - 2004. Mar 30. Vol. 170 (7). - P. 1134-1137.

11. Kissela B. Clinical prediction of functional outcome after ischemic stroke: the surprising importance of periventricular white matter disease and race / B. Kissela, C.J. Lindsell, D. Kleindorfer // Stroke. - 2009. - Vol. 40, № 2. - P. 530-536.

12. Lifestyle risk factors for ischemic stroke and transient ischemic attack in young adults in the Stroke in Young Fabry Patients study / B. von Sarnowski, J. Putaala, U. Grittner [et al.] // Stroke. - 2013. - Vol. 44, № 1. P. 119-125.

13. The high risk of stroke immediately after transient ischemic attack: a population-based study / M.D. Hill, N. Yiannakoulias, T. Jeerakathil [et al.] // Neurology. 2004. - Vol. 62, № 11. - P. 2015-2020.

\section{СРАВНИТЕЛЬНЫЙ АНАЛИЗ ФАКТОРОВ РИСКА И КЛИНИЧЕСКИЕ ПОКАЗАТЕЛИ ТЯЖЕСТИ СОСТОЯНИЯ ПАЦИЕНТОВ С ТРАНЗИТОРНЫМИ ИШЕМИЧЕСКИМИ АТАКАМИ И В РАЗЛИЧНЫЕ ПЕРИОДЫ ИШЕМИЧЕСКОГО ИНСУЛЬТА}

\section{Г.В. Бессмертная, Ю.А. Бессмертный}

Резюме. В статье представлены результаты сравнительного анализа факторов риска и клинических показателей тяжести состояния больных с преходящими ишемическими атаками и в разные периоды ишемического инсульта. Установлено, что среди факторов риска цереброваскулярной патологии первое место занимает артериальная гипертензия (у 80 \%), на втором месте - курение табака (у 40 \%), ожирение выявлено у трети пациентов, ишемическая болезнь сердца - у 10 \%. Тяжесть состояния пациентов, выраженность нарушений жизненных и когнитивных функций зависят от типа инсульта и эпизодов повторного нарушения мозгового кровообращения.

Ключевые слова: факторы риска, артериальная гипертензия, ишемическая болезнь сердца, ожирение, курение, инсульт.

\section{COMPARATIVE ANALYSIS OF RISK FACTORS AND CLINICAL FINDINGS OF PATIENT'S CONDITION SEVERITY WITH TRANSIENT ISCHEMIC ATTACKS AND IN DIFFERENT PERI- ODS OF ISCHEMIC STROKE}

\section{G.V. Bezsmertna, I.A. Bezsmertnyi}

Abstract. The article presents the results of a comparative analysis of risk factors and clinical indicators of severity of patients with transient ischemic attacks and in different periods of ischemic stroke. It was found that among the risk factors 
for cerebrovascular disease arterial hypertension ranks first $(80 \%)$, tobacco smoking is only second (40\%), obesity was found in one third of patients with ischemic heart disease - in $10 \%$. The severity of the condition of the patients, the severity of violations of life and cognitive functions depend on the type of stroke and repeated episodes of cerebrovascular dysfunction.

Key words: risk factors, hypertension, coronary heart disease, obesity, smoking, stroke.

Scientific research institute of invalid rehabilitation of Pirogov national medical university (Vinnytsia)

Рецензент - проф. В.М. Пашковський

(ㄷ Г.В. Безсмертна, Ю.О. Безсмертний, 2015
Buk. Med. Herald. - 2015. - Vol. 19, № 4 (76). - P. 10-14

Надійшла до редакції 16.09.2015 року 